\title{
Surgery as a component of universal healthcare: Where is South Africa?
}

Conditions that can be treated or alleviated by surgical, obstetric and anaesthesia services, collectively termed surgical care, account for approximately one-third of the total global burden of disease. ${ }^{[1]}$ In November 2018, the Southern African Development Community (SADC) passed an intergovernmental resolution ${ }^{[2]}$ that recognised surgical care as an indispensable component of Universal Health Coverage (UHC) to attain global health and the Sustainable Development Goals (SDGs) ${ }^{[3]}$ and to affirm 2015 World Health Assembly Resolution WHA68.15. ${ }^{[4]}$ SADC health ministers, including the former South African Minister of Health, Dr Aaron Motsoaledi, pledged to invest in surgical care by developing National Surgical, Obstetric and Anaesthesia Plans (NSOAPs). Three non-SADC African countries (Ethiopia, Rwanda and Nigeria) and two SADC countries (Tanzania and Zambia) are implementing NSOAPs, while four other member states (Botswana, Malawi, Namibia and Zimbabwe) are developing them. Although South Africa (SA) has promoted the concept of UHC, it has not taken any concrete steps to meaningfully include surgical care in its new National Health Insurance (NHI) policy.

SA has one of the most inequitable health systems in the world. ${ }^{[5,6]}$ The national health system has been under international scrutiny ${ }^{[7]}$ since the adoption of NHI, a health system payment reform to improve the quality of healthcare and address the disparities in health service provision. Surgical care is an indispensable, crosscutting health service that is necessary to improve health in diverse areas such as cancer, injury, cardiovascular disease, infection, and maternal/child health. ${ }^{[8]}$ The high burdens of trauma, noncommunicable diseases ${ }^{[8]}$ and communicable diseases (HIV and tuberculosis in particular) are a triple threat to the health and wellbeing of South Africans. It is projected that without an essential and emergency surgical package that is accessible to all South Africans, beginning at first-level (district) facilities, the country will experience significant gross domestic product (GDP) workforcerelated productivity losses. ${ }^{[9]}$ Substantial investment in surgical care is an important prerequisite for the realisation of SA's National Development Plan, ${ }^{[10]}$ the government's current strategy to promote macroeconomic growth, which aims to improve basic welfare and citizen capabilities through a more efficient state service delivery in health and other sectors. Large segments of the young working population may be unable to contribute to this broader societal development process if afflicted by untreated surgical conditions. ${ }^{[11]}$ For an upper middle-income country like SA, failing to invest in surgical care could result in GDP losses of up to $2 \%$ by the year 2030 as a result of premature disability and mortality. ${ }^{[12]}$

To improve surgical care, the National Department of Health $(\mathrm{NDoH})$ could utilise the NSOAP framework, as a 'systems'based and fully costed approach, to deliver an essential surgical package through NHI. In 2015, a National Surgical Forum was convened at the University of Witwatersrand to discuss a roadmap for an NSOAP following the launch of the Lancet Commission on Global Surgery (LCoGS). Since then, perioperative research has been conducted in SA to quantify the LCoGS indicators and identify health system gaps in workforce, ${ }^{[13,14]}$ infrastructure ${ }^{[15-17]}$ and quality. ${ }^{[18-20]}$ While more than $96 \%$ of South Africans live within 2 hours of a government hospital, ${ }^{[21]}$ quality surgical care is variable and lags behind global standards. ${ }^{[20]}$ Governance, financing, service delivery, infrastructure, the workforce and data systems must be optimised to improve surgical outcomes at a national level.

Leadership from the $\mathrm{NDoH}$ has been lacking, but is desperately needed to mobilise internal political support for an NSOAP, including promoting the financing, implementation and integration of surgical care in the National Health Strategic Policy. ${ }^{[22]}$ Additional research is needed to identify innovative solutions for NSOAP governance, financing, workforce, service delivery, infrastructure and information management (Table 1). NSOAPs require complex health system reform, ${ }^{[23]}$ with co-ordination from the $\mathrm{NDoH}$, and a pragmatic approach to implementation that is easily understood by early adopters. Frontline providers, for example, will be the first to interact with the policy, requiring a change in how they function, behave, and adapt in changing hospital settings. ${ }^{[24]}$ Such an approach demands effective co-operation and partnerships across the stakeholder continuum, spanning academia, public and private sectors (including the biomedical sector), nongovernment organisations, civil society and, most importantly, patient representatives and advocacy groups.

SA could play an important leadership role in advancing the global and SADC resolutions by including an NSOAP in its NHI policy. We encourage the new Minister of Health, Dr Zweli Mkhize, to prioritise surgical care as a means to strengthen the SA health system and make progress towards the SDGs. ${ }^{[11]}$ This is likely to translate into significant improvement in the health and wellbeing of all South Africans.

\begin{tabular}{ll} 
Table 1. NSOAP priority areas \\
$\begin{array}{ll}\text { Health system reform/ } & \text { Examples of reform to capacitate } \\
\text { first-level facilities }\end{array}$ \\
\hline 1. Governance & $\begin{array}{l}\text { Actively support the decentralisation } \\
\text { of surgical care and improve referral } \\
\text { systems between hospital levels }\end{array}$ \\
& $\begin{array}{l}\text { Ensure appropriate financing for a } \\
\text { fully costed NSOAP through NHI } \\
\text { 2. Finance }\end{array}$ \\
$\begin{array}{l}\text { Promote workforce retention and } \\
\text { performance and provide skills } \\
\text { development based on evidence and } \\
\text { contextually based competencies } \\
\text { Institute protocol-based surgical care, } \\
\text { and strengthen auxilliary surgical }\end{array}$ \\
$\begin{array}{ll}\text { 4. Service delivery } & \text { services such as radiology, pathology, } \\
\text { blood transfusion and critical care } \\
\text { services } \\
\text { Ensure that first-level hospitals are }\end{array}$ \\
5. Infrastructure & $\begin{array}{l}\text { equipped to provide essential surgical } \\
\text { procedures } \\
\text { Strengthen information management } \\
\text { and structuring of data for ongoing } \\
\text { performance evaluation and data } \\
\text { analysis }\end{array}$ \\
&
\end{tabular}




\section{Ché L Reddy}

Program in Global Surgery and Social Change, Department of Global Health and Social Medicine, Harvard Medical School, Boston, Mass., USA; and Department of Plastic and Oral Surgery, Boston Children's Hospital, Harvard Medical School, Boston, Mass., USA

\section{Emmanuel M Makasa}

Cabinet Office, Government of the Republic of Zambia, Lusaka, Zambia; and Centre of Surgical Care for Primary Health and Sustainable Development, Faculty of Health Sciences, University of the Witwatersrand, Johannesburg, South Africa

\section{Bruce Biccard}

Department of Anaesthesia and Perioperative Medicine, Groote Schuur Hospital and Faculty of Health Sciences, University of Cape Town, South Africa

\section{Martin Smith}

Department of Surgery, Faculty of Health Sciences, University of the Witwatersrand and Chris Hani Baragwanath Academic Hospital, Johannesburg, South Africa

\section{Elmin Steyn}

Division of Surgery, Faculty of Medicine and Health Sciences, Stellenbosch University, Cape Town, South Africa

\section{Graham Fieggen}

Department of Surgery, Faculty of Health Sciences, University of Cape Town, South Africa

\section{Salome Maswime}

Department of Obstetrics and Gynaecology, Faculty of Health Sciences, University of the Witwatersrand, Johannesburg, South Africa

\section{John G Meara}

Program in Global Surgery and Social Change, Department of Global Health and Social Medicine, Harvard Medical School, Boston, Mass., USA; and Department of Plastic and Oral Surgery, Boston Children's Hospital, Harvard Medical School, Boston, Mass., USA

\section{Kathryn Chu}

Department of Surgery, Faculty of Health Sciences, University of Cape Town, South Africa; and Department of Global Health, Faculty of Medicine and Health Sciences, Stellenbosch University, Cape Town, South Africa

kchu@sun.ac.za
1. Shrime MG, Bickler SW, Alkire BC, Mock C. Global burden of surgical disease: An estimation from the provider perspective. Lancet Glob Health 2015;3:S8-S9. https://doi.org/10.1016/S2214109X(14)70384-5

2. Southern African Development Community Secretariat. Media statement - joint meeting of SADC Ministers of Health, 2018. https://www.sadc.int/files/3315/4169/8409/Media_Statement_-_Joint_ Meeting_of_SADC_Ministers_of_Health_and_those_responsible_for_HIV_and_AIDS_.pdf (accessed 3 May 2019).

3. United Nations Development Programme. Sustainable Development Goals. https://www.undp.org/ content/undp/en/home/sustainable-development-goals.html (accessed 20 February 2019).

4. World Health Organization. Strengthening emergency and essential surgical care and anaesthesia as a component of universal health coverage. 68th World Health Assembly Agenda Item 17.1. WHA68.15. 26 May 2015. http://apps.who.int/gb/ebwha/pdf_files/WHA68/A68_R15-en.pdf WHA68.15. 26 May
(accessed 3 May 2019).

5. Ataguba JE-O, Alaba O. Explaining health inequalities in South Africa: A political economy perspective. Dev South Afr 2012;29(5):756-764. https://doi.org/10.1080/0376835X.2012.730962

6. Coovadia H, Jewkes R, Barron P, Sanders D, McIntyre D. The health and health system of South Africa: Historical roots of current public health challenges. Lancet 2009;374(9692):817-834. https:// doi.org/10.1016/S0140-6736(09)60951-X

7. Makoni M. Health under the spotlight as South Africa takes to the polls. Lancet 2019;393(10183):17911792. https://doi.org/10.1016/S0140-6736(19)31001-3

8. Meara JG, Leather AJM, Hagander L, et al. Global Surgery 2030: Evidence and solutions for achieving health, welfare, and economic development. Lancet 2015;386(9993):569-624. https://doi. org/10.1016/S0140-6736(15)60160-X

9. Kabaniha G, Mwabu G, Kirigia J, Dovlo D. A Heavy Burden: The Indirect Cost of Illness in Africa. Kabaniha G, Mwabu G, Kirigia J, Dovlo D. A Heavy Burden: The Indirect Cost of Illness in Africa.
Brazzaville, Congo: World Health Organization, 2019. https://www.afro.who.int/sites/default/ files/2019-03/Productivity\%20cost\%20of\%20illness\%202019-03-21.pdf (accessed 29 April 2019).

10. South African Government. National Development Plan 2030. https://www.gov.za/issues/nationaldevelopment-plan-2030 (accessed 5 June 2019).

11. Roa L, Jumbam DT, Makasa E, Meara JG. Global surgery and the sustainable development goals. Br J Surg 2019;106(2):e44-e52. https://doi.org/10.1002/bjs.11044

12. Alkire BC, Shrime MG, Dare AJ, Vincent JR, Meara JG. Global economic consequences of selected surgical diseases: A modelling study. Lancet Glob Health 2015;3:S21-S27. https://doi.org/10.1016/ s2214-109x(15)70088-4

13. Dell AJ, Kahn D. Where are general surgeons located in South Africa? S Afr J Surg 2018;56(1):12-20. https://doi.org/10.17159/2078-5151/2018/v56n1a2393

14. Dell AJ, Gray S, Fraser R, Held M, Dunn R. Orthopaedic surgeon density in South Africa. World J Surg 2018;42(12):3849-3855. https://doi.org/10.1007/s00268-018-4709-4

15. Dell A, Kahn D. Surgical resources in South Africa: A review of the number of functional operating theatres. S Afr J Surg 2018;56(3):2-8. https://doi.org/10.17159/2078-5151/2018/v56n3a2253

16. Dell AJ, Kahn D. Geographical maldistribution of surgical resources in South Africa: A review of the number of hospitals, hospital beds and surgical beds. S Afr Med J 2017;107(12):1099-1105. https:// doi.org/10.7196/SAMJ.2017.v107i12.12539

17. Dell A, Kahn D, Klopper J. Surgical resources in South Africa: An analysis of the inequalities between the public and private sector. S Afr J Surg 2018;56(2):16-20. https://doi.org/10.17159/20785151/2018/v56n2a2397

18. Marsicano D, Hauser N, Roodt F, et al. Preoperative anaemia and clinical outcomes in the South African Surgical Outcomes Study. S Afr Med J 2018;108(10):839-846. https://doi.org/10.7196/ SAMJ.2018.v108i10.13148

19. Biccard BM, Madiba TE, Kluyts HL, et al. Perioperative patient outcomes in the African Surgical Outcomes Study: A 7-day prospective observational cohort study. Lancet 2018;391(10130):15891598. https://doi.org/10.1016/S0140-6736(18)30001-1

20. Bishop D, Dyer RA, Maswime S, et al. Maternal and neonatal outcomes after caesarean delivery in the African Surgical Outcomes Study: A 7-day prospective observational cohort study. Lancet Glob Health 2019;7(4):e513-e522. https://doi.org/10.1016/S2214-109X(19)30036-1

21. Juran S, Broer PN, Klug SI, et al. Geospatial mapping of access to timely essential surgery in subSaharan Africa. BMJ Glob Health 2018;3(4):e000875. https://doi.org/10.1136/bmjgh-2018-000875

22. National Department of Health, South Africa. Primary healthcare. http://www.health.gov.za/index. $\mathrm{php} /$ primaryhealthcare (accessed 5 June 2019).

23. Atun R, de Jongh T, Secci F, Ohiri K, Adeyi O. Integration of targeted health interventions into health systems: A conceptual framework for analysis. Health Policy Plan 2010;25(2):104-111. https://doi.org/10.1093/heapol/czp055

24. Atun RA, Menabde N, Saluvere K, Jesse M, Habicht J. Introducing a complex health innovation primary health care reforms in Estonia (multimethods evaluation). Health Policy 2006;79(1):79-91. https://doi.org/10.1016/j.healthpol.2005.12.005

S Afr Med J 2019;109(9):624-625. https://doi.org/10.7196/SAMJ.2019.v109i9.14233 